\title{
Beneficial Microorganisms: The Best Partner to Improve Plant Adaptative Capacity ${ }^{+}$
}

\author{
Beatriz Ramos-Solano ${ }^{1, * \mathbb{D}}$, Ana García-Villaraco ${ }^{1} \mathbb{D}$, Enrique Gutierrez-Albanchez ${ }^{2} \mathbb{D}$, Estrella Galicia ${ }^{1}$, \\ José A. Lucas ${ }^{1}$, Maria Belen Montero-Palmero ${ }^{1}$ and Francisco Javier Gutierrez-Mañero ${ }^{1}$ (1) \\ 1 Facultad de Farmacia, Universidad San Pablo-CEU Universities, 28668 Madrid, Spain; \\ anabec.fcex@ceu.es (A.G.-V.); estrellagcamp@gmail.com (E.G.); alucgar@ceu.es (J.A.L.); \\ mariabelen.monteropalmero@ceu.es (M.B.M.-P.); jgutierrez.fcex@ceu.es (F.J.G.-M.) \\ 2 Biobab R\&D, Bajada a Vargas 1 Agüimes, 35260 Las Palmas, Spain; diridbiol@biobab.net \\ * Correspondence: bramsol@ceu.es \\ + Presented at the 1st International Electronic Conference on Plant Science, 1-15 December 2020; \\ Available online: https://iecps2020.sciforum.net/.
}

Citation: Ramos-Solano, B.; GarcíaVillaraco, A.; Gutierrez-Albanchez, E.; Galicia, E.; Lucas, J.A.; Montero-

Palmero, M.B.; Gutierrez-Mañero, F.J. Beneficial Microorganisms: The Best Partner to Improve Plant Adaptative Capacity. Biol. Life Sci. Forum 2021, 4, 102. https://doi.org/10.3390/ IECPS2020-08639

Academic Editor: Yoselin

Benitez-Alfonso

Published: 1 December 2020

Publisher's Note: MDPI stays neutral with regard to jurisdictional claims in published maps and institutional affiliations.

Copyright: (c) 2020 by the authors. Licensee MDPI, Basel, Switzerland. This article is an open access article distributed under the terms and conditions of the Creative Commons Attribution (CC BY) license (https:/ / creativecommons.org/licenses/by/ $4.0 /)$.

\begin{abstract}
The world is currently facing a high population increase, as well as climate change involving global warming and water shortages, which limits the agronomic productivity necessary to achieve food security for the growing population. As sessile organisms unable to run away from danger, plants are endowed with sophisticated mechanisms to overcome all stressing situations for survival, involving an enormous amount of chemical molecules specific for each situation. In addition, they establish intimate relationships with beneficial microorganisms, creating the plant microbiome. Within this microbiome are beneficial bacteria, known as Plant Growth Promoting Rhizobacteria (PGPR), which represent a great tool to boost plant fitness in different aspects, as they are able to trigger multiple targets simultaneously. The present work describes the physiological mechanisms involved in plant adaptation to water stress, nutrient absorption, and adaptative responses to biotic stress, and how bio-effectors are able to modulate these responses, focusing on the mechanisms involved in plant adaptation to water stress (salinity and water shortage), plant innate immunity, and general mechanisms involved in plant protection to pathogen outbreaks. A few examples in Solanum lycopersicum, Olea europea and Rubus sp illustrate the effects of PGPR in increasing plant adaptative capacity.
\end{abstract}

Keywords: beneficial bacteria; adaptation; water stress; food

Supplementary Materials: The poster presentation is available online at https: / / www.mdpi.com/ article/10.3390/IECPS2020-08639/s1. 